\title{
(In)directness and complaints: a reassessment ${ }^{1}$
}

Decock, S. \& I. Depraetere.

2018. Journal of Pragmatics 132: 33-46.

In this, paper we reassess the notion of (in)directness as a tool for the analysis of complaint strategies. Starting from an overview of previous taxonomies of complaints, we show that (in)directness has been used to capture both the degree of explicitness and the degree of face-threat. We argue that it is necessary to disentangle both understandings of (in)directness in order to arrive at a clearer understanding, the distinction between linguistic (in)directness and perceived face-threat being key to the classification of complaint strategies. The proposal, which is based on extensive data analysis of CMC business complaints (e-mail and social media), is more in tune with current theoretical and methodological advances in pragmatics, and it offers accurate insights into degrees and types of linguistic (in)directness in complaints across contexts.

\section{Introduction}

The goal of this paper is to reassess the notions of directness and indirectness in the study of speech acts. We are not the first to point out that, although directness and indirectness are common concepts in pragmatics, there is no unanimous view on the features they capture. According to Haugh (2015: 39), indirectness "encompasses a broad range of quite disparate phenomena that are arguably not well explained within any single theoretical paradigm", and Grainger and Mills (2016: 34) point out in a similar fashion that scholars "do not always see the need to define [indirectness] but when they do, the definitions can vary considerably and are sometimes inconsistent and contradictory." Already in a paper published in 1985, Wierzbicka argued that "terms such as 'directness' or 'indirectness' are much too general, much too vague to be really safe in cross-cultural studies, unless the specific nature of a given cultural norm is spelled out." (1985: 175) More recently, this terminological confusion even led Silverstein (2010: 338) to question the usefulness of indirectness as an analytical tool altogether.

The analysis of complaints makes it particularly clear that the concepts of directness and indirectness need to be reassessed. Our interest was triggered while investigating the pragmatics of business complaint communication in customer-company correspondence in CMC (computermediated-communication) (see Author ${ }_{\mathrm{a}}$ 2015, Author a and Spiessens 2017a/b, De Clerck et al. subm.). When systematically describing the linguistic realizations of complaints and their interactional

1 We are very grateful to the anonymous reviewers and to Nicolas Ruytenbeek, for their useful comments on a draft of this paper. 
dynamics, a range of discursive strategies and features can be examined, ranging from strategies of objectification, narration, identity construction, authenticity, audience involvement, evaluation and stance (e.g. Vasquez 2014, Dayter and Rüdiger 2014, Drew and Walker 2009) to levels of directness (e.g. House and Kasper 1981, Olshtain and Weinbach 1993, Trosborg 1995, Hartford and Mahboob 2004, Tanck 2002, Meyer 2007, Meinl 2010, Chen et al. 2011). With respect to the study of directness in complaints, it is important to make a preliminary terminological point: most work on complaints uses the terms 'directness' and 'indirectness' to designate differences at the linguistic level (how is the complaint formulated?) and politeness effects. In an influential paper published in 1993, however, Boxer draws a distinction between 'direct complaints', complaints addressed to the person or organization responsible for the offence or capable of remedying, and 'indirect complaints', which are complaints addressed to a third party, i.e. someone other than the person or organization responsible for the offence. Boxer's distinction thus relates to differences in the complaint situation with regard to the participation framework (which parties are present when a complaint is being uttered?). When reassessing the concepts of directness and indirectness in this paper, we are not referring to Boxer's distinction, but to work on complaints which uses these terms to describe linguistic features of complaints.

Our paper starts with a critical evaluation of previous conceptualizations and applications of directness and indirectness in studies on complaints. This evaluation will pave the way for a more accurate method to analyze (in)directness in complaints, inspired by key findings in pragmatics (see e.g. Terkourafi 2012: 629): we will clarify the notions of directness and indirectness in the light of the interactional approach, with the aim of using them in an unambiguous and fruitful way for purposes of categorization and taxonomy. This involves making explicit the features the terms cover, and spelling out their link with politeness. The overall aim is that of developing a useful instrument that allows for the systematic cross-linguistic analysis of (in)directness in different speech acts.

\section{Directness and indirectness in previous studies on complaints}

Taxonomies of speech act strategies are very often based on the binary distinction between direct and indirect strategies and/or on the distinction between different directness levels. As far as complaints are concerned, complaint realization strategies have been generally categorized by means of a directness scale, without a clear line being drawn between direct and indirect strategies. Two of these scales have proven highly influential in work on complaints: the directness scale developed by House 
and Kasper (1981) in their paper on complaints and requests in German and English, and the directness scale developed by Trosborg (1995) in her book on requests, complaints and apologies in native and non-native English.

House and Kasper (1981: 159-167) identify eight levels on an indirectness-directness continuum, which relies on four criteria:

(1) P (= action which speaker judges to be bad for him/her) is mentioned implicitly or explicitly;

(2) X's (= the complainer's) negative evaluation of P is expressed explicitly;

(3) Y's (= the complainee's) agentive involvement is implicitly or explicitly expressed, and

(4) The negative evaluation of both $Y^{\prime}$ s action and $Y$ himself are implicitly or explicitly expressed.

Table 1 gives an overview of the continuum developed by House and Kasper. They illustrate each category with self-drafted examples.

\begin{tabular}{|c|c|c|}
\hline 1 & $\begin{array}{l}\text { By performing the utterance } U \text { in the presence of } Y, X \text { implies that he } \\
\text { knows that } P \text { has happened and he implies that } Y \text { did } P\end{array}$ & $\begin{array}{l}\text { Odd, my blouse was perfectly clean last } \\
\text { night }\end{array}$ \\
\hline 2 & By explicitly asserting that $P, X$ implies that $Y$ did $P$ & There's a stain on my blouse \\
\hline 3 & By explicitly asserting that $\mathrm{P}$ is bad for him, $\mathrm{X}$ implies that $\mathrm{Y}$ did $\mathrm{P}$ & Terrible, this stain won't ever come off \\
\hline 4 & $\begin{array}{l}\text { By explicitly asking } Y \text { about the conditions for the execution of } P \text { or } \\
\text { stating that } Y \text { was in some way connected with the conditions for the } \\
\text { doing of } P, X \text { implies that } Y \text { did } P\end{array}$ & Did you wear my blouse by any chance? \\
\hline 5 & $X$ explicitly asserts that $Y$ did $P$ & You've stained my blouse \\
\hline 6 & $\begin{array}{l}\text { By explicitly asserting that the action } P \text { for which } Y \text { is agentively } \\
\text { responsible is bad, or explicitly stating a preference for an alternative } \\
\text { action not chosen by } Y, X \text { implies that } Y \text { is bad/or } X \text { asserts explicitly that } \\
Y \text { did } P \text { and that } P \text { is bad for } X \text {, thus also implying that } Y \text { is bad }\end{array}$ & $\begin{array}{l}\text { You shouldn't have taken my blouse } \\
\text { without asking my permission } \\
\text { You have ruined my blouse }\end{array}$ \\
\hline 7 & $X$ asserts explicitly that $Y^{\prime}$ 's doing of $P$ is bad & $\begin{array}{l}\text { I think it's mean that you just take my } \\
\text { things }\end{array}$ \\
\hline 8 & $X$ asserts explicitly that $Y$ is bad & You are really mean \\
\hline
\end{tabular}

Table 1. Complaint strategies in House and Kasper (1981)

Level 1 is labelled as the "most indirect", while level 8 is labelled as the "most direct". In the case of level 1, the complaint is implicated; in all the other cases, it is either the bad action, negative feelings of the complainer, the fact that $Y$ performed the bad action, the negative evaluation of $Y$ or a combination of these elements that is explicitly mentioned. House and Kasper assume that on "all the lower levels the addressee $Y$ must perform an inference process on the basis of the situational context. [...] Through this inference process $Y$ is enabled to work out for himself both an adequate propositional content and the intended illocutionary force of X's utterance." (1981: 159-160) In other words, for House and Kasper, when complaints are "more indirect", the addressee goes through an inference process that 
results in the recognition of a specific utterance as a complaint. Even though the authors use explicitness and implicitness as an analytical tool, we feel there is a second underlying principle driving their continuum: the assumed degree of face-threat. Our interpretation is inspired by observations like the following: an expression such as "you are really mean" (level 8) cannot be considered more explicit than "you have ruined my blouse" (level 6), but, at least from a Western cultural perspective, it might be intuitively considered to be more face-threatening, and hence, more 'direct'. Likewise "I think it's mean that you just take my things" (level 7) is no more explicit than "You shouldn't have taken my blouse without asking my permission" (level 6), but these utterances may well differ in terms of facethreat.

The overall taxonomy in Trosborg's work on complaints (1995: 315-372) is based on the same criteria and is therefore fairly similar to House and Kasper's. She likewise identifies eight strategies, with strategy 1 being the most indirect one and strategy 8 the most direct one. The author uses selfdrafted examples to illustrate the different categories.

\begin{tabular}{|c|c|c|}
\hline 1 & $\begin{array}{l}\text { Hints: the complainer does not mention the complainable in the } \\
\text { proposition }\end{array}$ & $\begin{array}{l}\text { There was nothing wrong with my car } \\
\text { yesterday. }\end{array}$ \\
\hline 2 & $\begin{array}{l}\text { Expression of disapproval. Annoyance: the complainer explicitly asserts a } \\
\text { deplorable state of affairs }\end{array}$ & There's a horrible dent in my car. \\
\hline 3 & $\begin{array}{l}\text { Expression of disapproval. III consequences: the complainer explicitly } \\
\text { expresses the ill consequences resulting from an offence }\end{array}$ & $\begin{array}{l}\text { Oh damn it, l'll lose my insurance bonus } \\
\text { now. }\end{array}$ \\
\hline 4 & $\begin{array}{l}\text { Accusation. Indirect accusation: the complainer asks the hearer } \\
\text { questions about the situation or asserts that the hearer was in some way } \\
\text { connected with the offense }\end{array}$ & $\begin{array}{l}\text { You borrowed my car last night, didn't } \\
\text { you? }\end{array}$ \\
\hline 5 & $\begin{array}{l}\text { Accusation. Direct accusation: the complainer directly accuses the } \\
\text { complainee of having committed the offence }\end{array}$ & Did you happen to bump into my car. \\
\hline 6 & $\begin{array}{l}\text { Blame. Modified blame: the complainer expresses modified disapproval } \\
\text { of an action for which the accused is responsible, or he/she states a } \\
\text { preference for an approach not taken by the accused }\end{array}$ & $\begin{array}{l}\text { Honestly, couldn't you have been more } \\
\text { careful. } \\
\text { You should take more care with other } \\
\text { people's cars. }\end{array}$ \\
\hline 7 & $\begin{array}{l}\text { Blame. Explicit blame (action/behavior): the complainer explicitly states } \\
\text { that an action for which the accused is held responsible is bad }\end{array}$ & $\begin{array}{l}\text { How on earth did you manage to be so } \\
\text { stupid. }{ }^{2}\end{array}$ \\
\hline 8 & $\begin{array}{l}\text { Blame. Explicit blame (person): the complainer explicitly states what is } \\
\text { implicit at all other levels, namely, that he/she finds the accused a non- } \\
\text { responsible social member }\end{array}$ & $\begin{array}{l}\text { Oh no, not again! You really are } \\
\text { thoughtless. }\end{array}$ \\
\hline
\end{tabular}

Table 2. Complaint strategies in Trosborg (1995)

Trosborg spells out her understanding of directness and indirectness in greater detail than House and Kasper; she explains the rationale behind her scale in the following way:

\footnotetext{
${ }^{2}$ Strictly speaking, this example given by Trosborg to illustrate her seventh strategy seems to belong more to her eighth strategy (explicit blame directed at the person).
} 
In a complaint, the utterance may only indirectly express the complainer's ill feelings towards the complainee, or these may be phrased in terms of a straightforward accusation or in terms of moral judgment. In the former case, the complainee has to perform an inference process to establish a link between what is said and what is intended on the basis of the situational context. By choosing a particular level of directness, the complainer decides on the conflict potential of the complaint. [...] [T] he directness scale of complaints is formulated according to a semantic scale which expresses the severity of the offence. (1995: 314)

The overview shows that both House and Kasper's and Trosborg's directness scales are based on two principles: on the degree of implicitness or explicitness and on the degree of face-threat. Capturing directness and indirectness in terms of implicitness and explicitness reflects the Gricean (1975) distinction between 'what is said' and 'what is implicated'. A speaker can be said to be indirect when she communicates to the hearer more than what she actually says and an implicature is inferred by the hearer. Searle (1975) speaks of 'indirect speech acts' when a specific illocutionary force is implicated (or communicated indirectly): "a sentence that contains the illocutionary force indicators for one kind of illocutionary act can be uttered to perform, IN ADDITION, another type of illocutionary act" (1975: 59). House and Kasper's and Trosborg's directness scales for complaints also capture the degree of implicitness or explicitness in terms of (different types of) an inference process: it is assumed that the more implicit ('indirect') complaint strategies involve a more elaborate inference process. Our claim that their scales also hinge on the degree of face-threat can be inferred from the way they are constructed and illustrated, as substantiated by Trosborg's reference to the 'conflict potential of the complaint' and the 'severity of the offence'. By equating a higher degree of directness to a higher degree of face-threat, these studies on complaints make the following assumptions:

(a) the degree of face-threat is inherent in specific linguistic strategies,

(b) face-threat is mainly a matter of speaker intention, and

(c) indirectness and politeness are correlated. ${ }^{3}$

\footnotetext{
${ }^{3}$ In a paper published in 1993 on interlanguage features of complaints, Olshtain and Weinbach develop their own directness scale for complaints. They explain that it is based on the "perception of the severity of the complaint", which they also describe as the "degree of face-threat" (1993: 110). Assumptions (a) to (c) are thus also inherent in their approach. They do not mention the degree of explicitness as an additional defining factor.
} 
It should be added that House and Kasper's exact position in their 1981 paper with regard to these assumptions is somewhat unclear or ambiguous. Their scale is clearly based on these principles, but in their conclusion, they acknowledge the existence of different politeness norms across cultures ("different social norms in English and German which govern the usage of these [directness] levels in interaction: attacking one's interlocutor's identity seems to be taboo in the British cultural context, while it seems perfectly appropriate behavior for Germans under specific interactional conditions" (1981: 183)), and they recognize that politeness is a perlocutionary effect:

In order to make valid statements about relative degrees of politeness of utterances in the two languages, it will surely always be necessary to take both components, directness levels and modality markers into account; however, in order to establish their relative value, an empirical investigation would have to be conducted, which examines the different perlocutionary effects various combinations of levels and classes of modality markers produce on the addressee (1981: 183).

House and Kasper's and Trosborg's directness scales are frequently adopted in recent studies on complaints which focus on (in)directness (e.g. Meyer 2007, Meinl 2010). However, given the fact that as from the 2000s, the understanding of directness and indirectness as operating in these previous studies on complaints has been challenged by numerous scholars and from different angles, a different system to categorize complaint strategies should at least be considered. Extensive criticism relates to the speaker-centeredness of earlier speech act and (im)politeness theories, which manifests itself for instance in the fact that face-threat and (im)politeness are primarily linked to speaker intention (assumption (b)). Eelen (2001) and Locher and Watts $(2005,2008)$ criticize this view by advocating a discursive, interactional approach to (im)politeness, an approach which has been widely adopted (see also Arundale 2006; Haugh 2007). Grainger and Mills (2016), for instance, argue in their recent study on directness and indirectness across cultures that the analysis of interaction includes both speaker intention and hearer evaluation, and that the evidence for both needs to be found in the interaction itself, by analyzing the ways in which meanings are negotiated and achieved collaboratively between participants in an interaction. An approach in terms of co-construction of meaning in interaction also impacts on assumption (a) mentioned above: indeed, it implies that the view that politeness and impoliteness are inherent in specific linguistic utterances also needs to be dismissed. As Fraser and Nolen already pointed out in 1980: "Politeness is totally in the hands (and ears) of the hearer" (1980:96). Another highly problematized assumption is the correlation between indirectness and politeness (assumption (c)). Early work in pragmatics (e.g. Searle 1975: 64; Brown and Levinson 1987) 
had cautiously put forward such a correlation, even though Brown and Levinson, who made the strongest claims in this respect, were aware of its restrictions when stating, for instance, that "one cannot simply always make generalizations across speech acts: for example, polite offers are often bald-on-record imperatives" (1987: 142). Several other studies have shown that it is by no means a general rule that indirectness is by definition a polite strategy, or alternatively, that a higher degree of directness implies a higher degree of impoliteness. For instance, Blum-Kulka (1987) found that in the case of requests, conventional indirectness is perceived as more polite than nonconventional indirectness, ${ }^{4}$ and Wierzbicka (1985) argues that the evaluation of specific speech act realizations in terms of directness and politeness varies cross-culturally and depends on social and cultural values and norms. As Haugh (2015: 15) sums up quite nicely, "indirectness (...) can in fact give rise to a whole range of interpersonal effects of which politeness is just one" - and the same goes for directness.

As pointed out before (p. 5), House and Kasper (1981) and Trosborg (1995) also assume that more indirect utterances require more cognitive work, a view which has been criticized from a relevance-theoretic and psycholinguistic perspective. As Gibbs (2002: 460) argues, listeners "need not automatically analyse the complete literal meanings of linguistic expressions before accessing pragmatic knowledge to figure out what speakers mean to communicate." This view ties in with the relevance-theoretic approach: Wilson and Sperber (2004) defend the view that the identification of explicit content, i.e. explicatures, is equally inferential as the recovery of implicatures (see also Christie 2007). Moreover, it has been argued by some that certain types of indirect speech acts (e.g. Can you pass the salt?) are actually understood as part of what speakers say, which means that they are derived as explicatures rather than implicatures (Groefsema 1992, see also Gibbs 2002, see Ruytenbeeck 2017 for an overview of findings in experimental pragmatics on the processing of indirect speech acts).

In the light of their interactional discursive approach to directness and indirectness, Grainger and Mills (2016) aim to reassess both concepts: they make a distinction between first-order indirectness, i.e. the interactants' perspectives on indirectness, and second-order indirectness, i.e. the researcher's theoretical assessment of it. When approaching indirectness from a theoretical perspective (second-

\footnotetext{
${ }^{4}$ Brown and Levinson consider conventional indirectness as a strategy of negative politeness. It is captured as follows: "the use of phrases and sentences that have contextually ambiguous meanings (by virtue of conventionalization) which are different from their literal meanings. In this way the utterance goes on record, and the speaker indicates her desire to have gone off record (to have conveyed the same thing indirectly)". (1987: 132) They explain: "The process of conventionalization can be thought of as 'short-circuiting' inferences, so that where A may be inferred from B (especially by practical reasoning), stating B with the intent to convey A can become, by routine association, an 'idiom' for A'. (1987: 290). A typical example is 'Can you pass me the salt?', which is not understood as a request for information, but has come to be understood as a request for action.
} 
order indirectness), they argue that it would be best to limit indirectness to off-record speech, that is, speech giving rise to implicatures. Their understanding of off-record speech excludes cases of conventional indirectness, which are considered to be on-record. When comparing House and Kasper's (1981) and Trosborg's (1995) theoretical conceptualization of directness and indirectness to that of Grainger and Mills (2016), it becomes clear that the latter is no longer based on the degree of facethreat, but only on the principle of implicitness or explicitness. Grainger and Mills' attempt at reassessing directness and indirectness is therefore definitely useful, but in the case of the analysis of complaints, it is not fine-grained enough. In our corpus of business complaint interactions in CMC, complaints are almost always formulated on-record, and it is necessary to distinguish more than one level of explicitness among these on-record complaint strategies.

Having presented previous work on complaints and the relative merits and shortcomings of taxonomies based on the notion of (in)directness, we will outline an alternative approach in the following section.

\section{Towards a new categorization of complaint strategies}

Before we present our approach to the categorization of complaints (Section 3.2), we will briefly describe the corpus on which it is based, with specific attention for the samples from which the examples in this paper are taken (Section 3.1).

\subsection{Corpus}

Most of our examples are taken from a corpus of 388 Dutch-language and 204 German-language authentic Twitter complaint interactions posted on the official Twitter page of the Belgian national railway company (Nationale Maatschappij der Belgische Spoorwegen, NMBS) and the German national railway company (Deutsche Bahn, DB) respectively. This corpus was collected through random sampling between January and March 2016 in the context of a qualitative pilot study, and - in line with ethical standards - all complaints were anonymized in order to avoid identification as much as possible. To be included in the Twitter complaint corpus, a problem with the services offered needs to be topicalized by the customer: she either makes the problem explicit in her initial post, or the fact that there is a problem becomes clear from the ensuing Twitter conversation with the railway company. In addition, a few of the examples in this paper stem from an e-mail corpus consisting of 104 German- 
language and 73 French-language authentic customer-company complaint negotiations in a businessto-business (B2B) setting. This corpus was collected through convenience sampling between November 2013 and June 2016 in order to analyze complaint realizations and complaint negotiations in this specific context. Correspondence took place between a Belgian company that is a worldwide supplier of spare parts for material handling and industrial equipment and its customers residing in Germany, Austria, Switzerland or France. As stipulated in the confidentiality agreement we negotiated with this company, we anonymized the name of the company and of its customers. ${ }^{5}$

\section{2. linguistic (in)directness vs. perceived face-threat}

Our overview of previous studies on complaints shows that (in)directness is an ambiguous term, in the sense that it captures explicitness and implicitness (of the proposition and illocutionary force communicated) as well as degree of face-threat (perlocutionary effect). As this approach to (in)directness is no longer in tune with recent theoretical advances in pragmatics as outlined above, we consider it crucial, from a conceptual point of view, to disentangle both understandings of (in)directness, and we suggest to do so in the following way: when applying the term '(in)directness' to refer to the researcher's assessment of what is implicated or not in the linguistic realization of a speech act, we propose to qualify the term and speak of 'linguistic (in)directness'. The degree of linguistic (in)directness is thus related to explicitness and implicitness. When dealing with perlocutionary effects, that is, with how addressees evaluate specific speech act realizations in terms of face-threat and politeness, we simply speak of 'perceived face-threat' or 'perceived (im)politeness'. By disentangling both understandings of (in)directness in the analysis of complaints, it is now possible to take into account the fact that some expressions which are categorized as linguistically indirect complaints might actually be judged by the receivers of the complaint as face-threatening and impolite and vice versa. Previous complaint taxonomies do not allow for such an analysis, as the two facets are fused into one overall concept of '(in)directness'.

Starting from the distinction between 'linguistic (in)directness' and 'perceived face-threat', we propose a new way to categorize complaints which is in line with insights from the interactional approach in pragmatics because it only focuses on the researcher's analysis of linguistic (in)directness without making claims about face-threat, as previous complaint taxonomies did. Indeed, the degree of

\footnotetext{
${ }^{5}$ We are grateful to the company for giving us access to their complaint interactions with customers.
} 
face-threat of a complaint cannot be determined by analyzing linguistic realizations of complaints, but can only be traced through interactional and perception analysis.

The researcher determines on the basis of her knowledge of the situational context - is there a complaint situation? -, if a specific utterance can be labeled a complaint. If so, it is analyzed in terms of linguistic (in)directness. In the case of a complaint, the speech act situation can be described as follows: the complainer disapproves (B) of a past or ongoing action or occurrence $(A)$ which does not conform to her expectations and interests. The consequences of this action or occurrence are at cost to the complainer, who holds the complainee (at least partly) responsible for the perceived offence (C) and who wants the complainee to remedy the perceived offence in some way (D). This definition of a complaint situation is based on previous definitions of complaints (Trosborg 1995: 15, Meinl 2010: 14), and it consists - as indicated above by the letters A, B, C and D - of four constitutive components:

(A) a past or ongoing action or occurrence (the complainable);

(B) the disapproval or negative evaluation of the complainable;

(C) the assumed agentive involvement of the complainee, and

(D) the wish for the offence to be remedied.

We consider our definition of a complaint situation to be cross-culturally valid, but, obviously, crosscultural variations pertain to the type of occurrences which give rise to a complaint situation (i.e. complaint reasons), the way complaints are linguistically realized, and perceptions of these complaint realizations.

In a complaint situation, the complainer will either opt out, i.e. not voice her complaint to the complainee, or when choosing to address and confront the complainee, she will choose a complaint strategy from a range of possible options, which vary in terms of linguistic (in)directness, i.e. explicitness and implicitness. The criteria for linguistic (in)directness can be made concrete and operational for data analysis by taking into account the presence or absence of either an explicit reference to the speech act (e.g. performative verb/noun), or an explicit reference to (one or more of) the constitutive component(s) of the speech act situation.

In the new complaint taxonomy we outline below, we distinguish six categories: we draw the line between implicit and explicit complaint strategies (category 1 vs. categories 2, 3, 4, 5, and 6), the distinction between categories 2 to 6 being based on whether there is an explicit reference to the 
speech act or an explicit reference to at least one of the constitutive components of the complaint situation. For each category or strategy, we will give a few examples of complaint realizations. Most examples stem from our complaint corpus (see 3.1). ${ }^{6}$ Using these examples allows us to give additional insights into the kinds of decisions that need to be taken when operationalizing our taxonomic principle and applying it to authentic data. We have also added a few self-drafted examples in most categories, because this makes it possible to compare different linguistic realizations of the complaint in the same complaint context. They also show that our new taxonomy does not only apply to customer-company complaints, but to a wider range of complaint types, including those occurring in everyday family settings. The self-drafted complaints are set against the following everyday complaint situation: the complainer, who lives together with her sister, left a closed letter on the living room table with the intention of opening and reading it the next day. However, she finds her letter already opened the next morning, and she believes her sister is responsible for this. Therefore, she voices a complaint to her sister.

\section{- Category 1: Hint or implicit complaint}

When there is no explicit reference to the speech act (through a verb or noun that names the speech act), and when all four constitutive components of the complaint situation are implicated, we consider the complaint to be realized off-record, as a hint, so in a fully implicit way; only the context, i.e. the complaint situation, gives clues as to the fact that a complaint is being performed. In the following Dutch-language example from the Twitter corpus, for instance, it is only the ensuing Twitter conversation with the railway company that allows us to identify this utterance as a complaint and not as a neutral request for information:

1)@NMBS zijn er problemen op de lijn Brussel-leuven? Op de trein richting Luik, met hoeveel vertraging in leuven moet ik rekening houden?

@NMBS are there any problems on the Brussels-Leuven line? On the train in the direction of Luik, what kind of delay should I expect there to be?

\footnotetext{
${ }^{6}$ We did not correct language mistakes when using examples from our authentic complaint corpus, and we have translated all Dutch-language, German-language, and French-language examples into English.
} 
Based on this first post, it can as yet not be determined whether the customer is actually experiencing problems; the questions could be interpreted as a factual inquiry (so that the customer might know at what time she will be arriving). When reading the Twitter conversation following this tweet, however, it becomes clear that the customer is already experiencing some problems and that the problems are the reason for the inquiry. This type of implicit complaint is extremely rare in our corpus. Related to the everyday complaint situation we described above, the example in (2) likewise illustrates the category of implicit complaint, as no explicit reference is made either to the speech act of complaining or to one of its constitutive components:

2) Next time I won't leave my letters on the table any more.

\section{- Category 2: Explicit reference to the speech act of complaint}

When a complaint is realized through a reference to the speech act (a verb or noun that explicitly names the speech act of complaint), we consider the complaint to be realized on-record. Based on a review of the complaint data in previous and our own studies, this type of complaint strategy seems to be typical of business contexts. ${ }^{7}$ In business complaints, this explicit complaint strategy is generally complemented with other complaint strategies by referring to one or more of the constitutive components of the complaint (see below), and it is often specialized business vocabulary that is used to explicitly refer to the act of complaining: the verb reklamieren or the noun Reklamation in German, and the verb to claim or the noun claim in English.

3) [Dieses Teil] ist defekt und wir möchten es reklamieren. [This part] is broken and we want to claim it.

In the following four categories, complaint strategies are distinguished in terms of the number of constitutive components of the complaint situation that are communicated on-record or explicitly. The more constitutive components a complainer communicates on-record, the more linguistically direct the complaint is considered to be. We use the terms 'explicit' and 'on-record' interchangeably, and we

\footnotetext{
${ }^{7}$ Vasquez (2011) also came across this strategy in her English-language data, which consist of Tripadvisor reviews, but it is only rarely used in this context.
} 
use them to refer to the Gricean notion of 'what speakers say' and to what Sperber and Wilson (2004) call 'explicature'.

\section{- $\underline{\text { Category 3: One constitutive component }}$}

This third category comprises complaint realizations in which only one constitutive element of the complaint situation is communicated on-record. In category 3 examples from the Twitter complaint corpus, the constitutive element which can be derived as an explicature is generally the complainable (A):

4)@NMBS jullie ticket automaat in Izegem is kapot er zijn geen tickets verkrijgbaar. $@ N M B S$ Your ticket machine in Izegem is broken there are no tickets available.

5)@DB_Bahn Sbahn S1 von Mannheim nach Neustadt steht 15min in Ludwigshafen ohne eine brauchbare Durchsage

@DB Sbahn (sic) 8 S1 from Mannheim to Neustadt has not moved for 15 minutes in Ludwigshafen without any relevant announcement being made.

6)@nmbs Waarom is de trein naar Gent van 18:23 al om 18:21 vertrokken? \#treingemist @nmbs Why had the 18.23 train to Ghent already left at 18:21? \#missedtrain

In examples (4) and (5), the complainable (A) is described in a declarative sentence, while in example (6), it is presupposed in the request for information. The following self-drafted examples demonstrate that there are further ways to make the complainable $(A)$ explicit:

7) Odd, yesterday this letter was still closed.

8) My letter is open.

9) My letter was opened.

10) Somebody opened my letter.

11) Who opened my letter?

12) Did you open my letter?

\footnotetext{
${ }^{8}$ The S-Bahn, an abbrevation for Schnellbahn (fast railway) or Stadbahn (city railway), refers to a passenger train in (sub)urban regions in Germany.
} 
In example (7), still is a presupposition trigger which communicates to the hearer, in combination with the state of affairs located in the past, that the letter is open now. In the examples in (9) and (10) the proposition explicitly communicated is that somebody opened the letter, but the complainer does not mention explicitly who she thinks did this. In example (11), there is a presupposition that somebody opened the letter; the complainer may well hold the hearer at least partly responsible, but does not communicate this explicitly. In the case of a yes/no question (example (12)), the complainable (my letter is open) is made explicit; the agentive involvement of the complainee (the predicative relation 'you-open the letter') is questioned.

\section{- Category 4: two constitutive components}

It is also possible to communicate two out of four constitutive components of the complaint situation on-record. The following examples from the Twitter complaint corpus illustrate the scenario in which the complainable (A) and disapproval of the complainable (B) are explicitly communicated:

13)@NMBS Dit gebeurt bijna wekelijks. Telkens een uur wachten op aansluiting \#kotsbeu @NMBS. This happens almost every week. Always waiting for an hour for a connecting train. \#sickandtiredofthis

14) @DB_Bahn \#IC2216 Wagen 9 völlig überheizt!!! Es ist wie in der Sauna! Nicht zum Aushalten! \#deutschenbahn \#db \#bahn

@DB_Bahn \#IC2216 Carriage 9 completely overheated!!! It's like a sauna! Unbearable! \#deutschenbahn \#db \#bahn"

15) @DB_Bahn AC7wtf?!? Einfach mal den regulären Fahrplan von einem auf den nächsten Tag um 14 Minuten (!) vor verlegen? 20

@DB_Bahn AC7wtf?!? Suddenly, the regular timetable shifts forward by 14 minutes (!) ?

16) @DB_Bahn Wieder seit Tagen die komplette Unterführung vermüllt \#Mühlheim Bahnhof SBahn yㅜㅇ

@DB_Bahn Again the complete undercrossing covered in litter for days \#Mühlheim Bahnhof SBahn w

In example (13), the customer expresses disapproval (B) of the complainable (A) verbally by signing with "sick and tired of this", while in example (14), B is realized both verbally ("Unbearable") and para- 
verbally, through the repetitive and successive use of exclamation marks. In example (15), we observe verbal ("wtf"), para-verbal (flooding of exclamation and question marks) and non-verbal (flooding of angry-face emojis) realizations of $\mathrm{B} .{ }^{9}$ In example (16), B is realized only non-verbally through the use of an angry-face emoji. Disapproval is a constitutive component which can easily be made explicit not only verbally, but also non-verbally (e.g. facial expressions, gestures) or para-verbally (e.g. intonation), because it is an evaluation, an affect, an emotion. As the previous examples indicate, non- and paraverbal expressions of disapproval can be communicated in CMC through the use of typical CMCfeatures such as emoticons/emoji expressing negative emotions, and special types of layout (underlining, caps, bold, flooding, i.e. deliberate, expressive repetition, of letters or punctuation marks). Example (17) shows that disapproval can also be expressed through sarcasm, a stylistic feature which we encounter quite frequently in the Twitter complaint corpus:

17)@NMBS Schitterend: 5 rijtuigen ipv 10 op IC1529 = in de 1ste klas staan. Waarom betalen we voor 1ste klas in dit geval?

@NMBS Just great! 5 carriages instead of 10 on IC1520 = standing up in first class. So why do we pay for a first class ticket?

Alternatively, the two components of complaints communicated explicitly can also be the complainable (A) and the agentive involvement of the complainee (C). In our Twitter complaint sample, customers resort to the combination of these two constitutive components only rarely, as in the following Dutchlanguage example, in which the customer makes it clear that a certain ticketing machine is still not fixed $(A)$ and that she expects the railway company to fix it $(C)$ :

18)@NMBS Btw, ik had jullie eerder al eens gemeld dat de mobib lezer bij de automaat in Turnhout niet werkte. Dat is nog altijd niet gefixt.

@NMBS By the way, I had reported once before that the MOBIB reader next to the ticket machine in Turnhout is out of order. This has not been fixed yet. ${ }^{10}$

Determining whether component $\mathrm{C}$ (agentive involvement) is communicated on-record or not can be a subtle interpretative act. In the following example, the possessive pronoun ("your") refers to the German Railways. However, it would not be accurate to claim that the use of the pronoun explicitly

\footnotetext{
${ }^{9}$ Although the German Railways are referred to at the end of the complaint in a hashtag section, we consider this to be an implicit reference to $C$ (see discussion of example (19)).

${ }^{10} \mathrm{MOBIB}$ is the Flemish equivalent of an Oyster card on the London tube or a British Railcard.
} 
establishes agentive involvement (C) as it does in example (18). We consider component $\mathrm{C}$ not be explicit; this example belongs in category 3 (one constitutive element is communicated explicitly):

19) @DB_Bahn Im ICE über den Telekom-Hotspot ist eure Großkunden-Buchungsseite kaputt. Es werden keine CSS-Daten geladen, alles sehr "roh"

@DB_Bahn In the ICE via the Telekom hotspot your booking website for key accounts doesn't work. No CSS data are being charged, all very "raw"

Applied to the letter complaint scenario, this is what the combination of the constitutive components $A$ and $\mathrm{C}$ might sound like:

20) Why did you open my letter?

21) You opened my letter.

Finally, the Twitter corpus features quite a few examples in which the complainable (A) as well as the wish that the offence be remedied (D) are combined, as in:

22) @NMBS IC408 is afgeschaft, dus geraak niet meer op tijd op bestemming Oudenaarde. Waar kan ik yicket terugbetaald krijgen?

@NMBS. IC408 has been cancelled, so I won't reach my destination Oudenaarde on time. Where can get my yicket (sic) refunded?

23)@DB_Bahn im ICE kein Strom an mehreren Plätzen. Kann das Zugpersonal da was richten/ prüfen?

@DB_Bahn No power in several seats on the ICE. Can the train staff fix/check this?

Component $D$ can also raise issues of interpretation, as example (24) illustrates:

24) @DB_Bahn Bis morgen Nachmittag wurden alle S-Bahnen ab meiner Station gestrichen. Welche Regelung gilt da bzgl. Fahrgastrechten?

@DB_Bahn All (sub)urban trains from my station have been cancelled until tomorrow afternoon. Which regulations apply when it comes to passenger rights?

The complainer inquires after regulations concerning passenger rights, and this inquiry takes the form of a wh-interrogative. It could be interpreted as a request for information which hints at (or implicates) 
the complainer's wish for the offence to be remedied (D). While component $D$ is explicitly communicated in examples (22) and (23), it is implicit in this example.

The combination of $A$ (the complainable) and $D$ (wish for the offence to be remedied) is also very common in our corpus of B2B complaint e-mails, as in the following French-language example, in which a French customer reports damage to the products she received (A), and consequently asks for these products to be replaced (D):

\section{5) Bonjour,}

Nous avons reçu ce matin les tuyaux rigides de la commande [number], comme vous pouvez le constater sur la photo (A) les deux tuyaux (ce sont ceux de droite) références [number] et [number] ont été reçus endommagés. Nous l'avons signalé sur le récépissé du transporteur.

(D) Merci de nous renvoyer ces deux pièces.

Bonne réception, Cordialement, [full name]

Hello, We received two rigid pipes this morning from order [number], as you can see in the picture the two pipes (it is those on the right) with reference numbers [number] and [number] were damaged upon arrival. We have mentioned this on the receipt provided by the shipping company.

Thank you for sending us these two items again.

I hope you will receive this message in good order and look forward to hearing from you soon. [full name]

\section{- Category 5: three constitutive components}

When voicing a complaint, a complainer can also choose to communicate three constitutive elements of the complaint situation on-record. In the following Twitter examples, the complainable (A), the disapproval of the complainable (B) and the agentive involvement of the complainee (C) are explicitly voiced:

26) @NMBS IC1532 alweer vertraging, moet ik dan toch een auto aanschaffen, ik kom teveel te laat op werk dankzij \#nmbs \#fail

@NMBS IC1532 is again delayed, should I perhaps buy a car after all, as I am late for work too often thanks to \#nmbs \#fail

27)@DB_Bahn IHR SEID EIN INKOMPETENTER SCHEIßHAUFEN MAN ZAHLT 88,90€ DAMIT MAN VON 12 FAHRTEN 4 VERSPÄTUNGEN UND 2 KOMPLETT AUSFÄLLE HAT. 
@DB_Bahn YOU ARE A BUNCH OF INCOMPETENT SHITHEADS WE PAY 88,90€ FOR 12 JOURNEYS, FOUR OF WHICH ARE DELAYED TWO ARE CANCELLED.

28)@nmbs 5mins vertraging zonder aankondiging op de trein van 23:45 denderleeuw-welle.WAT IS T PROBLEEM MET JULLIE?? 360

@nmbs 5 mins delay without an announcement on the 23:45 train denderleeuw-welle. WHAT IS WRONG WITH YOU?? ?360

Disapproval of the complainable (B) is expressed through the negative evaluation of the service provided ("fail") in example (26), through the insult - combined with caps - addressed at the organization's employees ("YOU ARE A BUNCH OF INCOMPETENT SHITHEADS") in example (27), and through the aggressive interrogative combined with caps, question marks and angry-face emojis ("WHAT IS WRONG WITH YOU?? (36) is ) in example (28). Agentive involvement of the complainee (C) is expressed by sarcastically thanking the company in example (26), and by addressing the insult and the aggressive interrogative directly at the company's employees in examples (27) and (28) respectively.

The following self-drafted example illustrates a combination of the complainable $(A)$, disapproval of the complainable (by pointing out that the course of action should not have occurred) ${ }^{11}$ (B) and agentive involvement of the complainee (C) in everyday complaints:

29) You shouldn't have opened my letter.

It is also possible to communicate the complainable $(A)$, the agentive involvement of the complainee (C) and the wish that the offence be remedied (D) on-record, as illustrated by the following two Twitter examples:

30) @DB_Bahn hier im RE 4865 ist ne Tür kaputt. Solltet ihr mal machen lassen. ;) Die ist so kraftlos dass sie in jeder Linkskurve aufgeht.

@DB_Bahn here in the RE4865 a door is broken. You might want to get this fixed. ;) It is so lacking in power that it opens whenever the train bears left.

\footnotetext{
${ }^{11}$ In Author ${ }_{b}$ (2017) it is argued that in sentences with a modal verb, non-finite have is polysemous; it can communicate four different meanings, counterfactuality being one of them. (cp. He should leave earlier with He should have left earlier; there was no need to stay until Greg arrived.) In the context of a complaint situation, have + perfect infinitive communicates counterfactuality.
} 
31) @db_bahn ihr könntet übrigens mal wieder eine echte Reinigung vom S-Echrdingen Bf veranlassen. Die Böllerreste treten sich langsam fest.

@db_Bahn By the way you might want to organize another genuine clean-up of the SEchrdingen Railway Station. The firecracker leftovers are slowly getting stuck

The wish that the offence be remedied (D) can be realized in various ways, for instance through a strong recommendation, as in (30) and in (31), ${ }^{12}$ or by voicing a threat, as in the following self-drafted example (which also combines $A, C$ and $D)$ :

32) If you open my letters again, I will never be able to trust you anymore.

- Category 6: four constitutive components

Finally, a complainer can communicate all four constitutive components of a complaint situation onrecord, as two Twitter examples $(33,34)$ and one self-drafted example (35) illustrate. Note that B (disapproval of the complainable) is realized para-verbally through the repetition of exclamation marks in examples (33) and (34):

33) @NMBS kunnen jullie in het vervolg de vrijdag meer wagons inleggen voor de verbinding gentsint-pieters richting de panne want die zit vol!!

@NMBS Could you organize more carriages on Fridays on the connection Gent-sint-pieters in the direction of de panne because the train is jam-packed!!

34) @db_bahn @eurobahn_info Neben dem DB-Verspätungsanzeiger ist nun auch der des ZRL am Bf Werl defekt. Kümmert euch endlich!! @soesteranzeiger @db_bahn@eurobahn_info Apartfrom the DB_delay announcer the one of the ZRL ${ }^{13}$ at the train station Werl is now also broken. Finally do something about it! @soesteranzeiger

35) This is not okay, please don't open my letters.

\footnotetext{
12 Quite interestingly, both the modal sollen (have to) and können (can) communicate a strong recommendation. They are both used in the conjunctive mood and therefore acquire a touch of tentativeness. It is especially the presence of "mal" which weakens the force of the verb of necessity in (30): might want to rather than should renders the effect of solltet mal in German. Might want to typically results in pragmatic strengthening; it is clear to both interlocutors that the complainer is formulating an order rather than a mere recommendation.

13 ZRL is the abbreviation of the Zweckverband Schienenpersonennahverkehr Ruhr-Lippe, an association for the passenger railway system in the Ruhr-Lippe region.
} 
The overview just given illustrates the taxonomic principle we use to spell out linguistic (in)directness: it is defined in terms of implicitness and degrees of explicitness. It is important to stress that in natural oral or written data, complaints are often realized interactionally over the course of several turns. In the case of our CMC business complaint data sets, this means that in a first step, the initial complaint emails or tweets can be categorized according to their degree of linguistic (in)directness, and in a second step, the ensuing complaint interaction (an e-mail exchange or a Twitter conversation) can be studied to see if the degree of linguistic directness increases in the course of the interaction, and if so, how and under which conditions this happens.

In order to position our approach more clearly with respect to previous approaches, we will classify a small selection of complaint examples as elicited in oral face-to-face role enactments by Trosborg (1995) in terms of our new taxonomy. We have chosen not to classify House and Kasper's and Trosborg's self-drafted examples (see Tables 1 and 2) for two reasons: first, in the context of our empirical study, we want to prioritize the classification of (more) authentic examples, in this case, the complaints realized through role enactments. Secondly, the contextual information about the complaint situation of the self-drafted examples is insufficient to judge whether components $A$ and $B$ are realized by other than verbal means. We have applied the same method as that used for the analysis of the Twitter corpus: the focus is on the first turn in the complaint interactions (elicited by Trosborg). ${ }^{14}$ The bracketed number after each example refers to Trosborg's ranking (from 1 to 8 , with 1 being the most indirect complaint, and 8 the most direct); we also mention the complaint situation for each example between brackets.

\begin{tabular}{|c|c|c|}
\hline $\begin{array}{l}\text { Category 4: two constitutive } \\
\text { components }\end{array}$ & $A+B$ & $\begin{array}{l}\text { I. "Well, look! I might as well start right out, I'm sick and } \\
\text { tired of this, you know, look at this place." (1) (Situation: } \\
\text { neglected cleaning roster) } \\
\text { II."I feel just about the opposite, I feel terribly } \\
\text { embarrassed about doing these exercises in the office." } \\
\text { (2) (Situation: dislike of gymnastics on the job) } \\
\text { III."Honestly, I'm sick and tired of this mess. Look at it, all } \\
\text { over the place". (2) (Situation: neglected cleaning roster) }\end{array}$ \\
\hline
\end{tabular}

\footnotetext{
${ }^{14}$ It should be noted that we could not always establish with absolute certainty whether the examples cited actually constitute the first turn. As mentioned in the previous paragraph, in the second stage of the analysis, the whole complaint interaction should be taken into account.
} 


\begin{tabular}{|l|l|l|}
\hline & $\mathrm{A}+\mathrm{C}$ & $\begin{array}{l}\text { IV."Where have you been now, you haven't cleaned your } \\
\text { room today." (6) (Situation: neglected cleaning roster) }\end{array}$ \\
\hline $\begin{array}{l}\text { Category 6: four constitutive } \\
\text { components }\end{array}$ & $\mathrm{A}+\mathrm{B}+\mathrm{C}+\mathrm{D}$ & $\begin{array}{l}\text { V."I have been very busy because I have to do a } \\
\text { presentation for tomorrow at a tutorial and I wonder if } \\
\text { you could turn the music down because I can't sleep, } \\
\text { you've been disturbing me all evening while I'm doing my } \\
\text { preparing so-“ (5) (Situation: noisy party) }\end{array}$ \\
\hline
\end{tabular}

Table 4. Examples from Trosborg (1995) according to new taxonomy

The small sample presented in Table 4 already shows that disentangling linguistic (in)directness from perceived face-threat leads to a different ranking from the one proposed by Trosborg. Category 4 contains complaint examples which were positioned, in Trosborg's taxonomy, on quite opposite sides of the directness spectrum. That is, it contains examples with a low directness value (examples I, II and III) as well as an example that illustrates a higher level of directness (example IV) on her scale. Furthermore, the comparison brings to light an interesting difference with regard to the realization of the complainable (A). In the written business complaint corpus that we analyzed, we did not find examples of first turns in which the complainable $(A)$ is realized through non-verbal means only, as in example I. This seems related to the different settings in which complaints are expressed: an oral faceto-face and (more) informal setting vs. a written business setting. In oral settings, the complainer, complainee and complainable (A) are often co-present (as in example I), and in view of this copresence, the complainable $(A)$ does not necessarily need to be made explicit through verbal means because it is already made explicit through non-verbal cues such as eye gaze or pointing (the participants looking and/or pointing at the complainable). In example I, the complainee is even given explicit instructions to look around: "look at this place". Moreover, in our business setting, it is more in line with the customer complaint script to mention the complainable (A) right away, i.e. in the first turn, whereas in more informal complaint situations, interactional scripts are probably more varied in this respect. We would obviously need much more data to corroborate and expand these preliminary observations, but they already suggest that the application of our detailed taxonomy to different types of complaint settings is likely to shed light on how the setting influences the complaint realization.

To conclude this section, we would like to highlight one further aspect that positions our model with respect to existing taxonomies. We have argued that it is crucial to meticulously tease apart linguistic (in)directness and perceived face-threat, and for this reason our approach is different from

\footnotetext{
${ }^{15}$ We have no information about the way in which this complaint was pronounced. If the complainer uses an angry or irritated tone of voice, she also realizes component $B$, this complaint illustrates category $5(A+B+C)$.
} 
previous accounts. However, specific insights from previous papers are useful and tie in with our approach, in particular, the practice of labelling and analyzing the different speech acts which are used to realize the component parts of the complaints, and the attention for different types of internal and external modification. In order to account for the stylistic differences in the linguistic realization of the constitutive components and to be able to identify and explain stylistic patterns, we argue that these analytic procedures, i.e. the identification of speech acts and modifiers, should be continued. We consider these procedures as the second step in our approach, which deserves attention once the complaints have been classified in one of the different categories of linguistic (in)directness that we have described. We will briefly illustrate this second step by giving some examples. Constitutive components can be realized through different speech acts: for instance, the complainable $(A)$ can be realized by simply describing it (assertion) (e.g. examples (4) and (5)) or by requesting more information regarding the complainable (example (6)); disapproval (component B) can be realized by voicing an insult (expressive) (example (27)) or a negative evaluation (e.g. example (26)); agentive involvement (C) can be expressed by using interrogatives (example (20)) (cf. the complaint strategy 'interrogation' in Chen et al. 2011) or assertions (example (21)); and the wish for the offence to be remedied (D) can be articulated through a request (e.g. examples (22) and (23) or a threat (example (32)). These observations imply that complaints are often realized through a combination of different speech acts, a feature which has been captured in previous research (e.g. Vasquez 2011) by describing them as 'speech act sets'. In addition, complaint strategies can be linguistically modified in a number of ways. A few examples from our Twitter complaint sample are given in Table 5 (see Trosborg 1995 for further examples of modification in complaints):

\begin{tabular}{|c|c|}
\hline Wish for the offence to be remedied (C); downtoner & $\begin{array}{l}\text { (30) @DB_Bahn hier im RE } 4865 \text { ist ne Tür kaputt. Solltet ihr } \\
\text { mal machen lassen. ;) Die ist so kraftlos dass sie in jeder } \\
\text { Linkskurve aufgeht. } \\
@ D \text { D_Bahn here in the RE4865 a door is broken. You might } \\
\text { want to get this fixed. ;) It is so lacking in power that it opens } \\
\text { whenever the train bears left }\end{array}$ \\
\hline Disapproval (B); understater & $\begin{array}{l}\text { (36) @NMBS } 1 \text { rechtstreekse verbinding ts Bxl-Centraal en } \\
\text { Brugge per uur in het weekend. Echt? } \\
\text { \#beetjeinmijngatgebeten } \\
\text { @NMBS } 1 \text { direct connection btw Bxl-Central and Bruges per } \\
\text { hour in the weekend. Really? \#abitannoyed }\end{array}$ \\
\hline $\begin{array}{l}\text { Wish for the offence to be remedied (D); politen } \\
\text { marker }\end{array}$ & $\begin{array}{l}\text { (31) @db_bahn ihr könntet übrigens mal wieder eine echte } \\
\text { Reinigung vom S-Echrdingen Bf veranlassen. Die Böllerreste }\end{array}$ \\
\hline
\end{tabular}




\begin{tabular}{|c|c|}
\hline & $\begin{array}{l}\text { treten sich langsam fest. } \\
@ d b \_ \text {Bahn By the way you might want to organize another } \\
\text { genuine clean-up of the S-Echrdingen Railway Station. The } \\
\text { firecracker leftovers are slowly getting stuck }\end{array}$ \\
\hline $\begin{array}{l}\text { Wish for the offence to be remedied (D); downtoner } \\
\text { (winking face emoticon) })^{16}\end{array}$ & $\begin{array}{l}\text { (30) @DB_Bahn hier im RE } 4865 \text { ist ne Tür kaputt. Solltet ihr } \\
\text { mal machen lassen. ¿_Die ist so kraftlos dass sie in jeder } \\
\text { Linkskurve aufgeht. } \\
@ D B \text { Bahn here in the RE4865 a door is broken. You might } \\
\text { want to get this fixed. ;) It is so lacking in power that it opens } \\
\text { whenever the train bears left }\end{array}$ \\
\hline Complainable (A); adverbial intensifier & $\begin{array}{l}\text { (37) @DB_Bahn die manuell gesprochenen Durchsagen in } \\
\text { Stuttgart-Schwabstrasse sind akustisch völlig unverständlich. } \\
\text { @DB_Bahn the announcements made over the tannoy in } \\
\text { Stuttgart-Schwabstrasse are acoustically completely } \\
\text { incomprehensible. }\end{array}$ \\
\hline Complainable (A); time intensifier & $\begin{array}{l}\text { (38) @DB_Bahn Grüße an das Zentrum der Inkompetenz! } \\
\text { Wieder fällt ein IC2 aus Leipzig aus. Fast jeden Tag eine neue } \\
\text { Überraschung, danke! } \\
@ D B \_ \text {Bahn Greetings to the center of incompetence! Again a } \\
\text { IC2 from Leipzig has been cancelled. Almost every day a new } \\
\text { surprise, thanks! }\end{array}$ \\
\hline Complainable (A); sarcasm & $\begin{array}{l}\text { (39) @NMBS zeer goed communicatie, afstappen in Melle } \\
\text { voor de vervangbus naar Wetteren.. Wij staan hier allemaal } \\
\text { mooi \#communicatie } \\
\text { @NMBS very good communication, get off in Melle to board } \\
\text { the replacement bus to Wetteren.. Now we stand here nicely } \\
\text { stranded \#communication }\end{array}$ \\
\hline
\end{tabular}

Table 4. Modification in complaints ${ }^{17}$

In previous studies on complaints and (in)directness, these stylistic differences are - together with different degrees of explicitness - also interpreted in terms of face-threat: it is assumed (a) that certain linguistic choices give less, and others more, space to the complainee to interpret the complaint and react to it and (b) that a reduction of the complainee's options to interpret and react to a complaint constitutes a threat to the negative face of the complainee. It is true that linguistic choice (that is, the choice of speech act used to realize a constitutive component, the use of modifiers of the type illustrated in Table 3, and the degree of explicitness) and level of face-threat cannot be strictly separated in the sense that it is possible that certain ways of voicing a complaint are more likely to be

\footnotetext{
${ }^{16}$ In our Twitter corpus, emoticons/emoji can thus fulfil two functions: when they express negative emotions, they realize component B non-verbally, and when they express positive emotions or humor (smiling or winking face) in a non-sarcastic way, they function as downtoners.

${ }^{17}$ The translations of examples 30 and 31 are provided in Section 3.2.
} 
perceived as face-threatening. However, since there is no one-to-one relation between linguistic realization and perceived face-threat, our point is that it is unwise to use a complaint taxonomy which assumes that there is. Our proposed taxonomy is therefore, as stated above, about linguistic (in)directness' (explicitness and implicitness), not about perceived face-threat. No claims with regard to face-threat and politeness are made, as these depend on the complainee's evaluation, the latter being determined by a wide range of linguistic and contextual factors. In other words, we are aware of the need for a detailed description: our complaint taxonomy is based on linguistic (in)directness (step 1), but it is also important to pay attention to the way in which each constitutive component is stylistically realized (step 2). However, as pointed out before, conclusions regarding face-threat and politeness can only be made on the basis of additional interactional and perception analysis.

\section{Conclusion}

The reassessment announced in the title of our presentation consists in resolving the ambiguity relating to (in)directness in previous studies on complaints by drawing a clear distinction between 'linguistic' (in)directness on the one hand and perceived face-threat on the other. In this paper, we have focused on linguistic (in)directness, which denotes the degree of explicitness of the complaint, and we have distinguished the following six complaint strategies:

1. implicit complaint: the four constitutive elements of a complaint are implicated;

2. presence of a verb/noun that names the speech act;

3. one constitutive element communicated on-record/explicitly;

4. two constitutive elements communicated on-record/explicitly;

5. three constitutive elements communicated on-record/explicitly;

6. four constitutive elements communicated on-record/explicitly

We illustrated our approach by giving (authentic) examples. We would like to stress three advantages of our proposal. First of all, it is data-driven; it stems from the coding of a vast corpus of CMC complaint data, which pinpointed problematic issues with existing taxonomies of complaint strategies. All of them mix up linguistic (in)directness and perceived face-threat, which results in inaccurate (cross-linguistic) claims. Secondly, our approach is more in tune with current theoretical and methodological advances in pragmatics (see Terkourafi 2012), and it respects the generally 
acknowledged distinction in linguistics between form and function. In our approach, form refers to the linguistic realization of the complaint, and function to its effect on the addressee. Thirdly, it offers accurate and innovative insights into degrees of explicitness (categories 2 to 6) and types of explicitness (depending on the specific combination of constitutive components and on the ways these constitutive components are made explicit) and can in this way serve as a useful tool for the categorization and analysis of complaints across contexts and cultures. Although our rigorous distinction between linguistic (in)directness and perceived face-threat turns the analysis of complaints into an even more time-consuming and complex endeavour, this is a necessary step to arrive at a better understanding of complaint strategies. Admittedly, the analysis of linguistic (in)directness is only a first step. As explained above, when aiming for a fine-grained description of complaint data it needs to be complemented with a detailed stylistic analysis of the different complaint realizations per strategy or category as a second step. Moreover, it is ideally followed by an analysis of perceived facethreat, i.e. by an interactional analysis and/or perception analysis which looks into how complaints are received in terms of politeness and face-threat. 
Arundale, Robert B. 2006. "Face as Relational and Interactional: A Communication Framework for Research on Face, Facework, and Politeness." Journal of Politeness Research. Language, Behaviour, Culture 2 (2): 193-216.

Blum-Kulka, Shoshana. 1987. "Indirectness and Politeness in Requests: Same or Different?" Journal of Pragmatics 11 (2): 131-146.

Boxer, Diana. 1993. "Social Distance and Speech Behavior: The Case of Indirect Complaints." Journal of Pragmatics 19 (2): 103-125.

Brown, Penelope, and Stephen C. Levinson. 1987. Politeness: Some Universals in Language Usage. Cambridge; New York: Cambridge University Press.

Chen, Xing, Lei Ye, and Yanyin Zhang. 1995. "Refusing in Chinese." In Gabriele Kasper (ed.), Pragmatics of Chinese as Native and Target Language, 119-163. Honolulu: University of Hawai'i Press.

Chen, Yuan-shan, Chun-yin Doris Chen, and Miao-Hsia Chang. 2011. "American and Chinese Complaints: Strategy Use from a Cross-Cultural Perspective." Intercultural Pragmatics 8 (2): 253-275.

Christie, Christine. 2007. "Relevance Theory and Politeness." Journal of Politeness Research 3 (2): 269-294.

Dayter, Daria, and Sofia Rüdiger. 2014. Speak your mind, but watch your mouth: complaints in CouchSurfing references. In Kristina Bedijs, Gudrun Held and Christiane Maaß (eds.), Face work and social media, 193212. Berlin: LIT Verlag.

Author. 2015.

Author ${ }_{a}$, and Anneleen Spiessens. 2017a.

Author $r_{a}$ and Anneleen Spiessens. 2017b.

De Clerck, Bernard, Author ${ }_{a}$, and Jasper Vandenberghe. (subm.).

Authorb. 2017.

Drew, Paul, and Traci Walker. 2009. "Going Too Far: Complaining, Escalating and Disaffiliation." Journal of Pragmatics 41 (12): 2400-2414.

Eelen, Gino. 2001. Critique of politeness theories. Manchester: St. Jerome's Press.

Fraser, Bruce and William Nolen. 1981. "The association of deference with linguistic form." International Journal of the Sociology of Language 27: 93-109.

Gibbs, Raymond W. Jr. 2002. "A new look at literal meaning in understanding what is said and implicated." Journal of Pragmatics 34: 457-486.

Grainger, Karen, and Sara Mills. 2016. Directness and Indirectness across Cultures. Basingstoke: Palgrave Macmillan.

Groefsema, Marjolein. 1992. "'Can You Pass the Salt?': A Short-Circuited Implicature?" Lingua 87 (1-2): 103135.

Hartford, Beverly, and Ahmar Mahboob. 2004. "Models of Discourse in the Letter of Complaint." World Englishes 23 (4): 585-600.

Haugh, Michael. 2007. "The discursive challenge to politeness research: an interactional alternative. Journal of Politeness Research 3: 295-317.

Haugh, Michael. 2015. Im/Politeness Implicatures. Berlin: De Gruyter.

House, Juliane, and Gabriele Kasper. 1981. "Politeness markers in English and German." In Florian Coulmas (ed.), Conversational routine: explorations in standardized communication situations and prepatterned speech, 157-185. New York: Mouton.

Koczogh, Helga V. 2014. "The development of a taxonomy of verbal disagreements in the light of the p-model." In András Kertész and Csilla Rákosi (eds.), The Evidential Basis of Linguistic Argumentation, 133-178. Amsterdam; Philadelphia: John Benjamins.

Locher, Miriam A., and Richard J. Watts. 2005. "Politeness Theory and Relational Work." Journal of Politeness Research 1 (1): 9-33.

Locher, Miriam A., and Richard J. Watts 2008. "Relational Work and Impoliteness: Negotiating Norms of Linguistic Behaviour." In Derek Bousfield and Miriam A. Locher (eds.), Impoliteness in language. Studies on its interplay with power in theory and practice, 77-99. Berlin: Mouton de Gruyter. 
Maíz-Arévalo, Carmen. 2014. "Expressing Disagreement in English as a Lingua Franca: Whose Pragmatic Rules?" Intercultural Pragmatics 11 (2): 199-224.

Muntigl, Peter and William Turnbull. 1998. "Conversational structure and facework in arguing." Journal of Pragmatics 29(3): 225-256.

Meinl, Marja Ebba. 2010. Electronic Complaints: An Empirical Study on British English and German Complaints on eBay. Dissertation, Bonn University. Available at: hss.ulb.uni-bonn.de/2010/2122/2122.pdf (accessed 4 April 2016).

Meyer, Katrin. 2007. Interkulturelle Pragmatik: Aufforderungen, Entschuldigungen und Beschwerden. Eine Untersuchung zur interkulturellen Sprechhandlungskompetenz deutscher Austauschschüler in den USA. Dissertation, Hamburg University. Available at: https://www.deutsche-digitalebibliothek.de/binary/T3IBA4QWLLGCTF46OVQCE3QJT4WEJ2CV/full/1.pdf (accessed 4 April 2016).

Olshtain, Elite and Liora Weinbach. 1993. "Interlanguage features of the speech act of complaining." In Gabriele Kasper and Shoshana Blum-Kulka (eds.), Interlanguage pragmatics, 108-122. Oxford: Oxford University Press.

Rees-Miller, Janie. 2000. "Power, severity, and context in disagreement." Journal of Pragmatics 32: 1087-1111.

Ruytenbeek 2017. "The comprehension of indirect requests: Previous work and future directions". In Depraetere, Ilse \& Raphael Salkie (Eds.), Semantics and Pragmatics. Drawing a Line, 293-322. Cham: Springer.

Searle 1975. "Indirect Speech Acts." In Peter Cole and Jerry L. Morgan (Eds.), 59-82. Syntax and Semantics. Vol. 3, Speech Acts, edited by New York: Academic Press.

Silverstein, Michael. 2010. "Direct' and 'indirect' communicative acts in semiotic perspective." Journal of Pragmatics 24(2): 337-353.

Tanck, Sharyl. 2002. "Speech Act Sets of Refusal and Complaint: A Comparison of Native and Non-Native English Speakers' Production." American University, Washington, DC. http://observer.american.edu/cas/tesol/pdf/upload/WP-2004-Tanck-Speech-Act.pdf.

Terkourafi, M. 2012. "Politeness and pragmatics." In Jaszczolt, Kasia \& Allan, Keith (Eds.) The Cambridge Handbook of Pragmatics. 617-137. Cambridge: Cambridge University Press.

Trosborg, Anna. 1995. Interlanguage Pragmatics: Requests, Complaints, and Apologies. Studies in Anthropological Linguistics 7. Berlin; New York: Mouton de Gruyter.

Vásquez, Camilla. 2011. "Complaints Online: The Case of TripAdvisor." Journal of Pragmatics 43 (6): 1707-17. doi:10.1016/j.pragma.2010.11.007.

Wierzbicka, Anna. 1985. "Different Cultures, Different Languages, Different Speech Acts: Polish vs. English." Journal of Pragmatics 9 (2-3): 145-178.

Wilson, Deirdre and Dan Sperber. 2004. "Relevance Theory." In Horn, L.R. \& Ward, G. (eds.), The Handbook of Pragmatics, 607-632. Oxford: Blackwell. 